\title{
APLIKATISI MODERASI DALAM INTERAKSI MUSLIM DAN NON-MUSLIM PERSPEKTIF TAFSIR NABAWI
}

\author{
Muhammad Alan Juhri ${ }^{1}$ \\ ${ }^{1}$ UIN Sunan Kalijaga Yogyakarta \\ Sleman, Yogyakarta, Indonesia \\ alanjuhri25@gmail.com
}

\begin{abstract}
Abstrak:
Fenomena banyak nya permusuhan, saling menyalahkan, dan membenarkan kelompoknya sendiri menjadi hal mengkhawatirkan dan mengancam intergrasi sosial yang ada. Agama sebenarnya mengecam sikap vigiliante menyakini kelompok dan agama merekalah yang benar, dan agama lain adalah agama yang salah. Islam sendiri memiliki aturan di dalam al-Qur'an dan Sunnah. Nabi Muhammad Saw selalu mengampanyekan Islam rahmatal lil alamin, dimana kalimat tersebut memiliki fungsi Islam sebagai agama pengayom, damai, sejahtera, dan tanpa diskriminasi. Hal ini telah di praktekan Nabi Saw sesuai Surah al-Mumtahanah ayat 8-9, Allah tidak melarang Nabi Saw untuk berbuat baik dan berbuat adil kepada orang non-muslim yang tidak memusuhinya. Lebih lanjut, dengan menggunakan metode deskriptif-analitis, dalam tulisan ini penulis menganalisis hadis-hadis Nabi yang menjelaskan ayat-ayat al-Qur'an mengenai relasi muslim dan non-muslim tersebut, agar nantinya dapat menjadi salah satu upaya dalam mewujudkan toleransi antar umat beragama.
\end{abstract}

Kata Kunci: Tafsir Nabawi, Relasi, Toleransi.

\begin{abstract}
:
The phenomenon of hostility, blaming each other, and justifying their own groups is alarming and threatens existing social integration. Religion actually condemns the attitude of vigilante, believing groups and their religion is right, and other religions are false religions. Islam itself has rules in the Qur'an and Sunnah. The Prophet Muhammad always campaigned for rahmatal lil alamin Islam, where the sentence has the function of Islam as a religion of protection, peace, prosperity, and without discrimination. This has been practiced by the Prophet according to Surah al-Mumtahanah verses 8-9, Allah did not forbid the Prophet to do good and do justice to non-Muslims who did not hostile him. Furthermore, using descriptive-analytical methods, in this paper the author analyzes the traditions of the Prophet that explain the verses of the Qur'an regarding Muslim and non-Muslim relations, so that later it can become one of the efforts in realizing tolerance between people religious.
\end{abstract}

Keywords: Tafsir Nabawi, Relation, Tolerance. 


\section{Pendahuluan}

Relasi muslim dengan non-muslim merupakan permasalahan klasik yang telah muncul semenjak masa Nabi Muhammad SAW dan para sahabatnya. Meskipun demikian, permasalahan ini masih tetap eksis dan masih ramai dibicarakan sampai saat ini. Bahkan boleh jadi akan menjadi isu menarik dikarenakan masih banyaknya kontroversi yang terkandung dalam permasalahan ini. ${ }^{1}$ Seperti misalnya terkait batasan bolehnya seorang muslim melakukan interaksi pada non-muslim. Pada kasus ini, terdapat pandangan yang begitu ketat membatasi relasi umat Islam serta non-Islam. Di sisi lain, juga ada pandangan yang cukup terbuka dan toleran dalam hal relasi umat Islam serta non-Islam ini. Bukan Cuma itu, melalui hubungan umat Islam serta non-Islam, seringkali muncul beragam konflik antar umat beragama. Bahkan hingga zaman modern saat ini. Sebut saja negara-negara di Timur Tengah, Syiria, Iran, Mesir, bahkan di Indonesia pun tidak jarang kita temui konflik yang disebabkan karena relasi antara muslim dengan non-muslim. ${ }^{2}$

Bagi seorang muslim, tentunya menjadi suatu kewajiban bagi kita untuk mencontoh dan meneladani Nabi Muhammad. Beliau ialah sosok panutan, akhlak serta kepribadian baiknya telah dijamin oleh Allah SWT (baca QS. Al-Ahzab: 21). Namun, perlu digarisbawahi bahwa mencontoh dan meneladani Nabi bukanlah merupakan persoalan yang sederhana, terlebih dalam hal mencontoh bagaimana sikap dan perilaku Nabi dalam berhubungan dengan orang-orang nonmuslim. Karena dalam sejarahnya, hubungan antara Nabi dengan non-muslim mengalami pasang surut dan tidak berjalan mulus. Artinya, hubungan antara Nabi dan non-muslim telah melewati masa-masa perdamaian dan pertikaian atau konflik. ${ }^{3}$ Sehingga dalam memahami dan meneladaninya butuh adanya pemahaman terhadap konteks yang melatarbelakangi sikap dan perilaku Nabi dalam berhubungan dengan non-muslim tersebut.

Di samping itu, perlu diyakini bahwa sikap, perbuatan, perkataan serta seluruh respon Nabi dalam menjalin hubungan dengan non-muslim ialah tidak terlepas dari petunjuk Allah SWT berupa wahyu. Banyak sekali ayat yang berbicara tentang hubungan antara umat Islam serta non-Islam. Baik itu ayat yang menceritakan tentang hubungan yang harmonis, seperti QS. Al-Mumtahanah: 89, maupun yang berbicara tentang hubungan yang disharmonis, seperti peperangan dan lain sebagainya, contohnya QS. At-Taubah: 36. Sementara itu, bila ayat-ayat semakna diinterpretasikan dengan riwayat-riwayat Nabi SAW, maka juga akan dijumpai hadis-hadis yang secara literal menjelaskan mengenai

${ }^{1}$ Fathur Rohman dan Ahmad Ali Munir, "Membangun Kerukunan Umat Beragama Dengan Nilai-Nilai Pluralisme Gus Dur”, Jurnal An-Nuha 5, no. 2 (2018): 158.

${ }^{2}$ Alwi Shihab, Islam Inklusif Menuju Sikap Terbuka Dalam Beragama, (Bandung: Mizan, 1997), 40.

${ }^{3}$ Alwi Shihab, Islam Inklusif Menuju Sikap Terbuka Dalam Beragama, 76-77. 
hubungan harmonis pada satu sisi, serta disharmonis (tidak harmonis) pada sisi lainnya. Seperti hadis tentang penghormatan Nabi kepada jenazah orang yahudi, dan pembebasan terhadap kaum kafir Żimmī, di mana hadis ini jelas bercerita tentang hubungan baik Nabi dengan non-muslim. Dan hadis tentang pemberlakuan jizyah, dan perintah memerangi non-muslim, yang menunjukkan bahwa Nabi juga pernah melakukan hubungan disharmonis dengan non-muslim. Terlepas dari konteks dari masing-masing hadis tersebut. ${ }^{4}$

Penulis mencoba untuk mengkaji lebih jauh tentang riwayat-riwayat Nabi yang menjelaskan tentang bagaimana beliau berhubungan dengan non-muslim. Dan dalam hal ini penulis menggunakan pendekatan tafsir nabawi, mengingat bahwa salah satu di antara fungsi hadis ialah untuk memberi penjelasan terhadap suatu ayat al-Qur'an. Maka kajian ini tak akan lepas dari ayat al-Qur'an yang menjelaskan tentang topik ini. Lalu hadis-hadis yang semakna dengan ayat alQur'an tersebut akan dipahami selaras dengan konteks agar nanti dapat diaplikasikan pada kehidupan sekarang ini demi mewujudkan masyarakat yang toleran, dan menjunjung tinggi nilai-nilai perdamaian.

\section{Tafsir Nabawi; Tinjauan Umum dan Ruang Lingkupnya}

Nabi Muhammad SAW merupakan penafsir pertama dan utama al-Qur'an. Saat turunya ayat, beliau lah yang menguraikan dan memahamkan kepada sahabat-sahabatnya tentang arti lafaz dan makna yang tersirat maupun tersurat dalam suatu ayat. Tafsir nabi merupakan termasuk dari embrio karya tafsir para alim-ulama, dimana mereka dapat menghasilkan dan menorehkan interpretasinya dalam sebuah kitab hadis, tafsir, fikih, dan ilmu lainnya. Maka tak heran jika riwayat, sanad ini memiliki kontribusi yang amat urgen serta besar bagi perkembangan ilmu agama terutama ilmu tafsir itu sendiri.

Mengingat ayat al-Qur'an yang jumlahnya teramat banyak, ${ }^{5}$ yaitu lebih kurang 6236 ayat. Maka timbul suatu persoalan, Apa Nabi Muhammad menafsirkan keseluruhan ayat tersebut/tidak? Jika tidak, maka seberapa banyak riwayat dari Nabi terkait interpretasi ayat ini?. Ada dua pandangan ulama terkait persoalan ini. Pertama, pandangan yang mengatakan bahwa Nabi SAW telah menafsirkan keseluruhan ayat Al-Qur'an, diantara ulama yang berpandangan begini yakni Ibnu Taimiyah. Kedua, pandangan yang mengatakan bahwa Nabi belum menafsirkan Al-Qur'an secara kesuluruhan, melainkan Nabi hanya

4 Ja'far Assagaf, "Hubungan Muslim Dengan Non-Muslim Perspektif Hadis" (Pascasarjana UIN Syarif Hidayatullah Jakarta, Tahun 2008), 3.

5 Tri Hijriyanti, "Peranan Pembimbing dalam Meningkatkan Hapalan Al-Qur'an Santri," Irsyad: Jurnal Bimbingan, Penyuluhan, Konseling, dan Psikoterapi Islam 6, no. 3 (2018): 327. 
menafsirkan sebagian ayat saja. Di antara yang berpandangan begini yakni AlKhuby. ${ }^{6}$

Masing-masing pandangan tersebut tentu saja memiliki argumentasi dan alasan. Argumen kelompok pertama, salah satunya yaitu berpegang pada firman

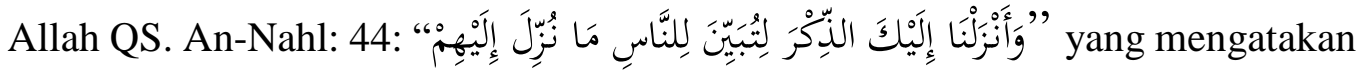
jika al-Qur'an diturunkan pada Nabi Muhammad agar dijelaskan maksudnya kepada manusia. Sedangkan kelompok kedua, salah satu argumennya yaitu berpegang pada riwayat al-Bazzar dari Aisyah yang mengatakan bahwa tidaklah Rasulullah SAW menafsirkan sebagian al-Qur'an kecuali dalam ayat yang sedikit, yang langsung diajarkan oleh jibril kepadanya. Di samping itu, riwayatriwayat Nabi terkait penafsiran al-Qur'an, jumlahnya hanya sedikit, maka ini menunjukkan bahwa beliau tak melakukan penafsiran atas semua ayat. ${ }^{7}$

Berdasarkan diskusi dari beberapa argumentasi masing-masing pandangan, maka penulis sepakat dengan pendapatnya pengarang kitab Tafsir an-Nabawiy, Muhammad 'Abd al-Rahīm, yang mengatakan pandangan kedua lah yang lebih kuat, yaitu bahwa Nabi tidak menafsirkan semua ayat, kecuali hanya di beberapa ayat saja. Namun, tulisan ini tidak membahas hal tersebut. Artinya, terlepas dari pandangan mana yang lebih kuat di antara keduanya, tulisan ini lebih mengarah kepada bagaimana ruang lingkup cakupan tafsir Nabi terhadap ayat.

Salah satu metode penafsiran menggunakan tafsir bil ma'tsur ${ }^{8}$ yakni dengan cara melakukan penafsiran al-Qur'an dengan hadits. Di sini Nabi Muhammad menerima wahyu dari Allah (SWT) berupa ayat. Ayat tentu tidak dipahami secara tekstual melainkan juga ada orang yang mencontohkan. Nabi Saw yang mempraktekan sesuatu yang tak jelas dalam al-Qur'an baik berupa tindakan maupun ketetapan merupakan sebuah metode yang digunakan tafsir bil ma'tsur. Dan ini sesuai dengan salah satu diantara kegunaan hadis ialah guna menjelaskan makna yang terkandung di al-Qur'an. ${ }^{9}$

\section{Interaksi Sosial Dalam Pandangan Islam}

Islam dalam perkembangannya merupakan agama yang bertujuan untuk menyebarkan rahmah, sebagaimana misi Nabi Muhammad SAW yang diutus oleh Allah SWT menjadi seorang Rasul. Hal ini dapat kita lihat melalui sejarah penyebaran agama Islam pada masa awal. Konflik antar keyakinan sering terjadi pada masa Rasulullah SAW, terutama konflik kaum Musyirikin (Yahudi dan orang-orang Musyrik) yang menolak kedatangan agama Islam yang dibawa Nabi

\footnotetext{
${ }^{6}$ Muhammad 'Abd al-Rahīm, Al-Tafsīr al-Nabawī Khașāiṣuhu wa Maṣādiruḥu (Kairo: Maktabah Az-Zahra', 1992), 7-8.

${ }^{7}$ Muḥammad 'Abd al-Rahīm, Al-Tafsīr al-Nabawī Khașāiṣuhu wa Maṣādiruḥu , 9-11.

8 Ratnah Umar, "Jāmi 'Al-Bayān 'An Ta'wīl Āyi Al-Qur'ān (Manhaj/Metode Penafsirannya)," Al Asas 1,2 (2018): 16.

${ }^{9}$ Isa Ansori, “Tafsir Al-Qur'an Dengan Al-Sunnah,” Kalam 11, no. 2 (2017): 524.
} 
Muhammad SAW. Namun kendatipun mendapat penolakan, seiring berjalannya waktu agama Islam dapat diterima dengan baik bahkan dapat berkembang secara besar-besaran. ${ }^{10}$

Agama Islam merupakan agama yang berpedoman kepada al-Quran dan Hadis. Istilah pluralisme bukanlah suatu hal yang asing bagi umat Muslim, sebagaimana yang telah banyak disebutkan dalam al-Quran tentang keberagaman ciptaan-Nya. Salah satu ayat yang menerangkan hal tersebut adalah surah alHujarat ayat 13:

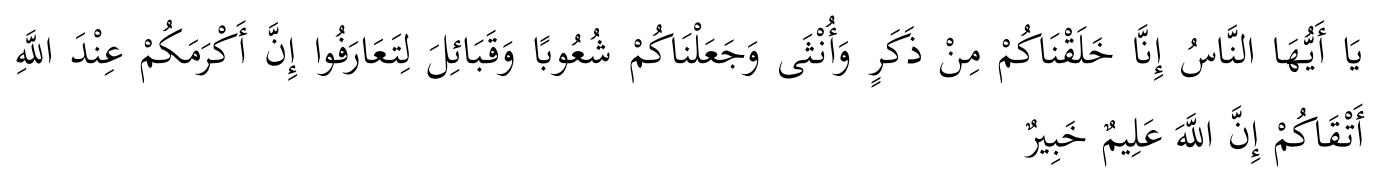

Artinya: "Hai manusia, sesungguhnya Kami menciptakan kamu dari seorang laki-laki dan seorang perempuan dan menjadikan kamu berbangsabangsa dan bersuku-suku supaya kamu saling kenal mengenal.”

Secara sederhana dapat kita pahami bahwa ayat diatas memberikan kita pemahaman supaya manusia mampu kenal-mengenal sesamanya walaupun terdapat perbedaan diantaranya.

Beberapa ulama' berpendapat tentang batasan-batasan interaksi antara muslim dengan non-muslim diantaranya:

A. Menurut Prof. Quraish Shihab, dalam tafsir al-Misbah, bahwa relasi seorang Muslim dengan non-Muslim dalam hal berinteraksi itu diperbolehkan selagi hubungan itu tidak menimbulkan sesuatu yang buruk bagi keduanya.

B. Buya Hamka, dalam tafsir al-Azhar, mencontohkan perilaku Nabi Saw kala itu, yang mana Nabi Saw merangkul semua orang baik itu umat Islam, Yahudi, dan Nasrani dengan terciptanya Piagam Madinah. Dari perilaku Nabi Saw tersebut jelas Nampak bahwa Nabi Saw sendiri berhubungan baik dengan kaum non-Muslim. ${ }^{11}$

C. Imam al-Rāzi berpandangan bahwa, Allah (SWT) berfirman dalam Q.S. Yunus: 99 "jikalau Tuhanmu berkehendak niscaya seluruh penduduk bumi akan beriman semua." Ayat ini menegaskan bahwa semua manusia bebas memilih agama dan kepercayaan ritual ibadahnya sendiri tanpa ada intervensi. Imam al-Razi juga mengatakan bahwa memilih iman itu bebas tanpa ada paksaan dari siapapun. Maka dari itu dalam hal berinteraksi

\footnotetext{
${ }^{10}$ Roro Sri Rejeki dan Lia Ulfah Farida, "Pola Interaksi Sosial Keagamaan Antara Penganut Agama Islam dan Kristen," Jurnal Religious 2, no.2 (2018): 85.

${ }^{11}$ Muhammad Arif Mustofa, "Kerukunan Umat Beragama (Studi Analisis Tentang Non Muslim, Ahlul Kitab \& Pluralisme)," Mizani 9, no. 1 (2015): 8.
} 
sesame manusia tidak boleh ada sekat atau memaksa seseorang untuk mengikuti agama tertentu.

D. Ahmad Mushthafa al-Maraghi berpendapat terkait hubungan Muslim dengan non-Muslim bahwa ketika seorang Muslim terlibat interaksi sosial dengan orang-orang non-Muslim itu di perbolehkan. Allah (SWT) tak membatasi umat muslim melakukan kebaikan terhadap orang kafir yang tidak memusuhi orang Muslim. ${ }^{12}$

\section{Relasi Muslim dengan Non-Muslim Dalam Al-Qur'an}

1. QS. Al-Taubah: 29

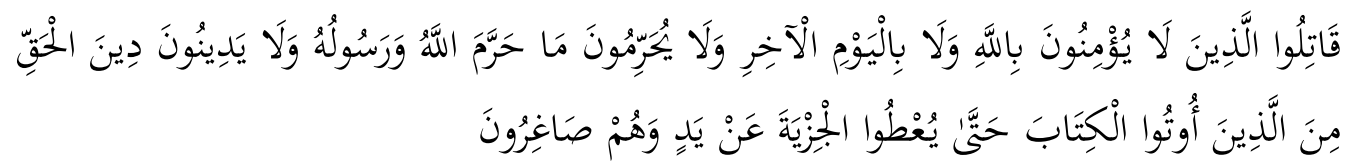

"Perangilah orang-orang yang tidak beriman kepada Allah dan tidak (pula) kepada hari kemudian, dan mereka tidak mengharamkan apa yang diharamkan oleh Allah dan Rasul-Nya dan tidak beragama dengan agama yang benar (agama Allah), (yaitu orang-orang) yang diberikan Al-Kitab kepada mereka, sampai mereka membayar jizyah dengan patuh sedang mereka dalam keadaan tunduk."

Ayat ini merupakan ayat yang pertama turun untuk memerintahkan umat Islam untuk memerangi Ahli-Kitab. Tepat pada tahun 9 Hijriyah ketika Jazirah Arab sudah mulai stabil turunlah perintah Allah tersebut. Hal ini didasarkan bahwa mereka sejatinya kafir, bukan saja tidak mempercayai Rasulullah saja namun risalah para nabi sebelumnya juga telah mereka ingkari. ${ }^{13}$ Karena apabila mereka berpegang teguh kepada risalah nabi-nabi sebelumnya tentulah mereka tidak akan menentang Rasulullah SAW. Hal ini diakibatkan karena mereka bukan berpegang teguh kepada syariat nabi sebelumnya, melainkan mereka hanya mengikuti kehendak hawa nafsu saja. Maka dari itu iman mereka kepada nabi terdahulu sangatlah sia-sia, karena mereka tidak mengimani penutup para nabi (khatamul anbiya') yaitu nabi Muhammad SAW. Untuk itu lah ayat ini diturunkan.

Dalam sebuah hadis yang telah masyhur disampaikan oleh para Imam Huffazh, dari riwayat 'Abdurrahman ibn Ghanim al-Asy'arī, Ia berkata ${ }^{14}$ : "Aku

${ }^{12}$ Dirun, "Hubungan Muslim Non-Muslim dalam Interaksi Sosial Study Analisis Penafsiran Thabathabai dalam Kitab Tafsir al-Mizan" (Universitas Islam Negeri Walisongo Semarang, 2015), 43-47.

${ }^{13}$ Hariyanto, "Relasi Kredibilitas Da'i Dan Kebutuhan Mad'u Dalam Mencapai Tujuan Dakwah," Tasamuh 15, no. 2 (2018): 65.

${ }^{14}$ Ibnu Kasīir, Tafsir Ibn Kasīir, Jilid 4 (t.k: Darut Taibah: 2001),110-114. 
mengirimkan surat kepada Umar Ra, ia memberikan perjanjian damai kepada orang-orang Nasrani dari penduduk Syam: 'Dengan menyebut nama Allah Yang Maha Pemurah lagi Maha Penyayang, Sebuah surat untuk hamba Allah, Umar Amirul Mukminin, dari orang-orang Nasrani kota ini dan ini. Sesungguhnya ketika kalian datang kepada kami, kami meminta jaminan keamanan untuk diri, anak, harta dab pemeluk agama kami. Kalian mensyaratkan agar kami tidak membangun tempat peribadatan yang menjadi rute-rute jalan orang Islam. kami tidak boleh melarang seorang muslim pun singgah di gereja kami siang ataupun malam hari pintu gereja harus selalu terbuka untuk orang-orang yang selalu dalam perjalanan. Kita diharuskan menjamu orang muslim yang berada dalam perjalan selama tiga hari. Gereja dan rumah kami tidak boleh menjadi tempat persembunyian mata-mata, atau yang menipu kamu muslimin."'

Selanjutnya kami tak diizinkan mengajarkan al-Qur'an pada anak-anak kami. Tidak di ijinkan memperlihatkan kesyirikan dan menyeru kepadanya. Tidak boleh melarang kerabat-kerabat kami yang hendak masuk ke dalam Islam. Harus menghormati orang Islam. Diharuskan mengutamakan orang Islam yang hendak duduk dalam suatu majlis. Tidak diperbolehkan menyerupai rupa orang Islamdalam berpakaian, tutup kepala, sandal, model sisiran rambut. Tidak boleh berbicara dengan bahasa kaum muslimin. Tidak memakai sebutan yang digunakan oleh kaum muslimin. Tidak boleh menggunakan pelana ketika berkendara. Tidak boleh membawa senjata. Tidak menjual khamr. Kami diharuskan memendekan rambut bagian depan. Kami harus selalu menganakan pakaian seragam kami. Tidak diperbolehkan memperlihatkan salib-salib di gereja-gereja, dan tidak diperbolehkan memperlihatkan salib ataupun kitab suci kami di jalan-jalan dan pasar-pasar kaum muslimin. Kami tidak diperbolehkan memukul lonceng gereja, kecuali seringan mungkin. Tidak boleh meninggikan suara kami ketika membaca kitab suci kami di gereja di hadapan orang-orang Islam. Kami tidak boleh menjadi utusan. Tidak boleh meniggikan suara ketika ada pengikut kami yang meninggal. Kami tidak boleh menyalakan lampu di jalanjalan dan di pasar-pasar kaum muslimin. Tidak boleh mengubur jenazah kami di pemakaman kamum muslimin. Kami tidak diperbolehkan mengambil budak sahaya sebagaiman yang boleh dilakukan kaum muslimin. Kami tidak boleh mengganggu privasi mereka." 15

Ia berkata: "Ketika surat itu telah sampai ketangan Umar, Ia menambahkan beberapa hal, kami tidak diperbolehkan memukul seseorang pun dari kaum muslimin. Syarat ini berlaku bagi diri kami dan warga megara kami, serta kami terima sebagai pengganti rasa aman. Jika kami melanggar persyaratan tersebut,

${ }^{15}$ Ahmad Sanusi Azmi, and Mohd Yusuf Ismail, "Konsep Rahmatan Lil Alamin Dalam Hadith: Penerokaan Makna Serta Aplikasi Di Malaysia," Journal of Hadith Studies 3, no. 1 (2018): 2. 
maka kami tidak mendapatkan perlindungan tersebut dan kami boleh diperlakukan sebagai para penentang."

2. QS. Al-Mumtahanah: 8-9

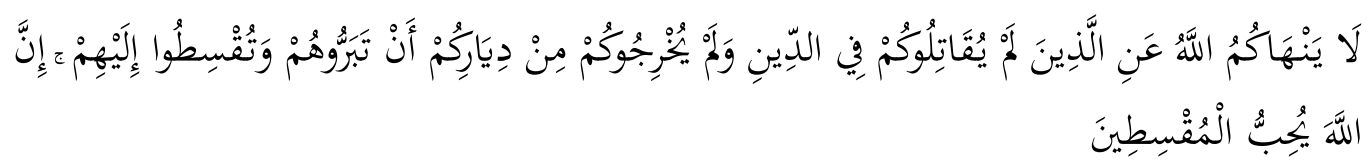

"Allah tidak melarang kamu untuk berbuat baik dan berlaku adil terhadap orang-orang yang tiada memerangimu karena agama dan tidak (pula) mengusir kamu dari negerimu. Sesungguhnya Allah menyukai orang-orang yang berlaku adil."

Ayat diatas menjelaskan bahwa Allah memperbolehkan umat Islam untuk berbuat baik terhadap orang kafir dengan catatan mereka tidak memusuhi orang Islam dan bersikap adil.

Imam Ahmad meriwayatkan dari Asma' bint Abu Bakar Ra, Ia bercerita, "Ibuku pernah datang kepadaku sedang Ia dalam keadaan Musyrik pada waktu kaum Quraisy mengadakan perdamaian (Hudaibiyyah). Lalu kukatakan: 'Ya Rasulullah, sesungguhnya ibuku datang kepadaku dan berharap (dia dapat bertemu denganku), apakah aku boleh menyambung hubungan dengannya?' Beliau menjawab: 'Ya, sambunglah hubungan dengan ibumu.'” (HR. Al-Bukhari dan Muslim). ${ }^{16}$

Imam Ahmad juga meriwayatkan, 'Arim memberitahukan kepada kami, 'Abdullah bin al-Mubarak memberitahu kami, Mush'ab bin Tsabit memberitahu kami, 'Amir bin 'Abdullah bin az-Zubair memberitahu kami, dari ayahnya, Ia bercerita: "Qutailah pernah datang menemui putrinya Asma' binti Abi Bakar dengan membawa daging dhabb (biawak) sedang Ia seorang musyrikah. Maka Asma' pun menolak pemberiannya itu dan memasukkan ibunya ke rumahnya. Kemudian 'Aisyah bertanya kepada Nabi Muhammad SAW. Lalu Allah SWT menurunkan ayat tersebut. Kemudian beliau menyuruh Asma' menerima pemberian ibunya itu dan mempersilahkannya masuk (ke dalam rumahnya Asma')." Demikian hadis yang dirawayatkan oleh Ibnu Jarir dan Ibnu Abi Hatim.

${ }^{16}$ Ibn Kas̄īr, Tafsir Ibn Kàī̄r, 118. 
Dan firman Allah sesungguhnya Allah menyukai orang-orang yang berlaku adil." Penafsiran ini dapat kita sandarkan kepada sabda Rasulullah SAW: ${ }^{17}$

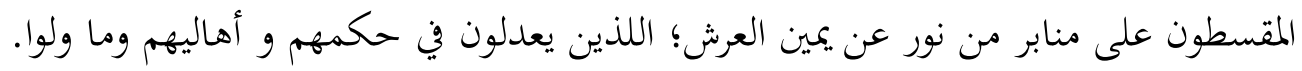

"Orang-orang yang berbuat adil di sisi Allah pada hari Kiamat kelak berada di atas mimbar-mimbar yang terbuat dari cahaya di sebelah kanan 'Arsy, yaitu orang-orang yang berbuat adil dalam hukum, keluarga, dan semua yang berada di bwah kekuasaan mereka."

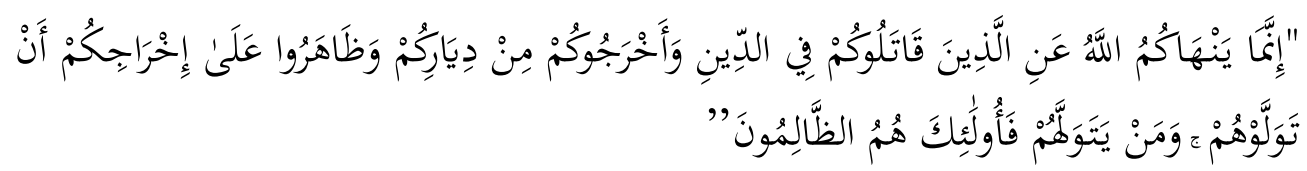

"Sesungguhnya Allah hanya melarang kamu menjadikan sebagai kawanmu orang-orang yang memerangimu karena agama dan mengusir kamu dari negerimu, dan membantu (orang lain) untuk mengusirmu. Dan barangsiapa menjadikan mereka sebagai kawan, maka mereka itulah orang-orang yang zalim."

Ayat diatas memberikan penjelasan bahwa Allah (SWT) tidak membolehkan berinteraksi terhadap orang kafir yang telah memusuhi orang Islam karena melihat dari agamanya bahkan sampai mengusir umat Islam dari negerinya. Allah (SWT) berfirman: "ومن يتولهم فأولئك هم الظالمون") Dan barang siapa yang menjadikan mereka sebagai kawan, maka mereka itulah orang-orang yang dzalim".

3. QS. Al-Mumtahanah: 10

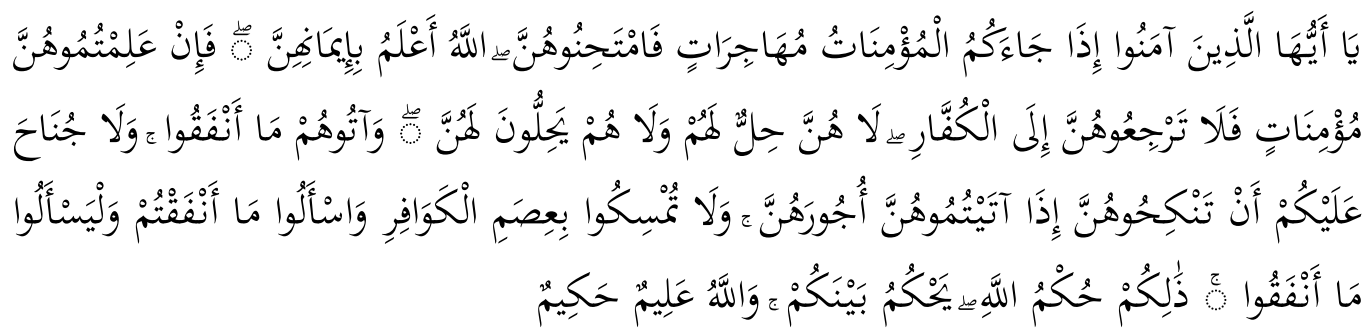

"Hai orang-orang yang beriman, apabila datang berhijrah kepadamu perempuan-perempuan yang beriman, maka hendaklah kamu uji (keimanan) mereka. Allah lebih mengetahui tentang keimanan mereka;

${ }^{17}$ Ibn Kas̄īr, Tafsir Ibn Kàī̄r, 119. 
maka jika kamu telah mengetahui bahwa mereka (benar-benar) beriman maka janganlah kamu kembalikan mereka kepada (suami-suami mereka) orang-orang kafir. Mereka tiada halal bagi orang-orang kafir itu dan orang-orang kafir itu tiada halal pula bagi mereka. Dan berikanlah kepada (suami suami) mereka, mahar yang telah mereka bayar. Dan tiada dosa atasmu mengawini mereka apabila kamu bayar kepada mereka maharnya. Dan janganlah kamu tetap berpegang pada tali (perkawinan) dengan perempuan-perempuan kafir; dan hendaklah kamu minta mahar yang telah kamu bayar; dan hendaklah mereka meminta mahar yang telah mereka bayar. Demikianlah hukum Allah yang ditetapkan-Nya di antara kamu. Dan Allah Maha Mengetahui lagi Maha Bijaksana."

Dalam perjanjian Hudaibiyyah ${ }^{18}$ antara Nabi Saw dengan orang kafir Quraisy dimana keduanya memiliki nota kesepakatan yang berbunyi; "tidak ada seorangpun dari kami yang mendatangimu meskipun ia memeluk agamamu melainkan engkau (Muhammad) harus mengembalikannya kepada kami." Dan dalam riwayat lain disebutkan: "Tidak seorangpun dari kami yang datang kepadamu meski sebagai pemeluk agamamu melainkan harus mengembalikannya kepada kami." Demikian adalah pendapat 'Urwah ad-Dhahhak, 'Abdurrahman bin Zaid, az-Zuhri, Muqatil bin Hayyan dan as-Suddi, berdasarkan riwayat ini, maka ayat ini mentakhsis (mengkhususkan) sunnah. Ini merupakan masalah terbaik, dan sebagai ulama' salaf memandangnya sebagai ayat nasikh (ayat yang menghapus). Karena sesungguhnya Allah Ta'ala telah memerintahkan kepada hamba-hamba-Nya yang beriman, jika wanita-wanita yang ikut berhijrah datang kepada mereka, hendaklah wanita-wanita itu diuji terlebih dahulu. Jika telah diketahui bahwa mereka itu adalah wanita-wanita yang beriman, maka mereka tidak boleh dikembalikan kepada orang-orang kafir. Karena wanita itu tidak halal bagi mereka dan begitu pula sebaliknya. ${ }^{19}$

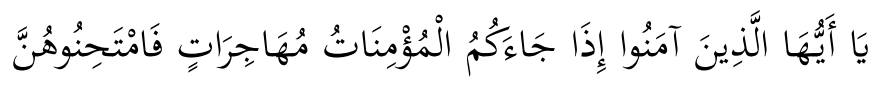

"Hai orang-orang yang beriman, apabila datang berhijrah kepadamu perempuan-perempuan yang beriman, maka hendaklah kamu uji (keimanan) mereka." Al-Aufi menceritakan dari Ibnu Abbas, Ia mengatakan: "bentuk pengujian beliau terhadap wanita-wanita itu adalah dengan meminta mereka mengucapkan syahadat: (Aku bersaksi bahwa tidak ada Tuhan selain Allah dan Nabi Muhammad utusan Allah), jika mereka mengucapkan hal tersebut maka mereka diterima."

${ }^{18}$ Rafli Difinubun, "Perjanjian Hudaibiyah (suatu Analisis Historis tentang Penyebaran Agama Islam di Jazirah Arab)," Rihlah: Jurnal Sejarah dan Kebudayaan 6, no.1 (2018): 65.

${ }^{19}$ Ibn Kas̄īr, Tafsir Ibn Kasīir, 120. 


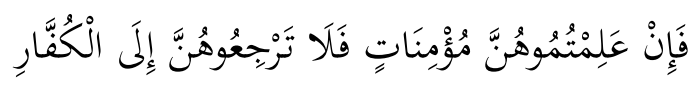

"Maka jika kamu telah mengetahui bahwa mereka (benar-benar) beriman maka janganlah kamu kembalikan mereka kepada (suami-suami mereka) orangorang kafir." Di dalamnya terdapat dalil yang menunjukan bahwa keimanan itu dapat dilihat secara pasti.

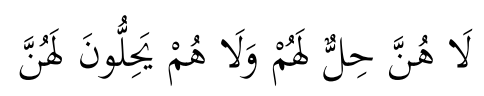

"Mereka tiada halal bagi orang-orang kafir itu dan orang-orang kafir itu tiada halal pula bagi mereka."

Ayat ini menerangkan bahwa haram bagi muslimah menikah dengan lakilaki non-muslim. Dahulu pada permulaan Islam, seorang non-muslim diperbolehkan menikah dengan wanita muslimah. Berdasarkan hal tersebut terlaksanalah pernikahan Abul 'Ash bin ar-Rabi' dengan puteri Rasulullah SAW, Zainab, dimana pada saat itu Zainab adalah wanita muslimah sedangkan Abul 'Ash masih memeluk agama kaumnya.

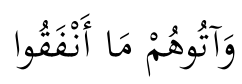

"Dan berikanlah kepada (suami suami) mereka, mahar yang telah mereka bayar." Maksudnya yaitu suami-suami para wanita yang berhijrah dari kalangan kaum musyrikin. Serahkanlah kepada mereka mahar-mahar yang telah mereka bauarkan kepada isteri-isteri mereka itu. Demikian yang telah dikemukakan oleh Ibnu Abbas, Mujahid, Qatadah, az-Zuhri dan lain-lain.

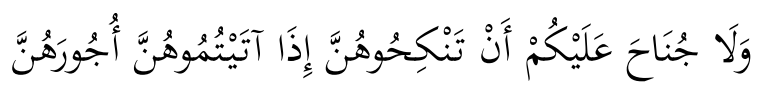

"Dan tiada dosa atasmu mengawini mereka apabila kamu bayar kepada mereka maharnya." Yakni jika kalian telah memberikan mahar kepada mereka, maka nikahilah mereka dengan tetap berpegang pada persyaratan, seperti telah selesainya masa iddah, adanya wali dan lain-lain.

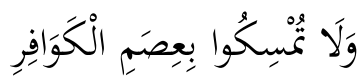

"Dan janganlah kamu tetap berpegang pada tali (perkawinan) dengan perempuan-perempuan kafir." Yang demikian merupakan pengharaman dari Allah SWT kepada hamba-hamba-Nya yang beriman. Yakni mereka diharamkan menikahi wanita-wanita musyrik dan tetap bertahan hidup berumah yanggan dengannya. 


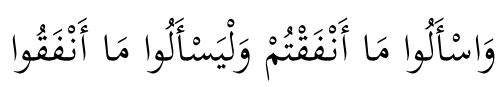

"Dan hendaklah kamu minta mahar yang telah kamu bayar; dan hendaklah mereka meminta mahar yang telah mereka bayar." Maksudnya, hendaklah kalian meminta kembali mahar dari isteri-isteri kalian yang pergi kepada orang kafir jika mereka pergi, dan hendaklah orang-orang kafir itu meminta kembali mahar dari isteri-isteri mereka yang berhijrah kepada kaum muslimin.

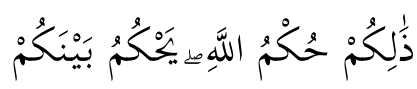

"Demikianlah hukum Allah yang ditetapkan-Nya di antara kamu." Yakni yang terdapat dalam perjanjian dan pengecualiannya untuk kaum wanita. Semua perkara ini adalah keputusan yang telah ditetapkan oleh Allah bagi semua hambaNya.

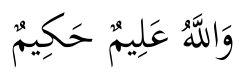

"Dan Allah Maha Mengetahui lagi Bijaksana." Yakni yang Maha Mengetahui apa yang terbaik bagi kemashlahatan hamba-hamba-Nya dan Maha Bijaksana dalam segala hal. ${ }^{20}$

\section{Riwayat Nabi Tentang Relasi Muslim dan Non-Muslim}

Sudah menjadi kewajiban bagi orang Muslim untuk mencontoh dan meneladani Nabi Muhammad SAW dalam menjalankan kehidupan di dunia. Tidak hanya dalam urusan relasi vertikal antara seorang hamba dan Tuhannya (ibadah), tetapi juga dalam urusan relasi horizontal antara seorang manusia dengan manusia lainnya (sosial). Hal ini telah jelas tertuang di dalam banyak ayat al-Qur'an yang menyatakan bahwa dalam diri Nabi SAW terdapat teladan yang baik (uswatun hasanah), dan setiap muslim wajib mengikuti beliau, dengan mematuhi segala yang diperintahkannya, menjalankan sunnah-sunnahnya, serta menjauhi segala larangannya.

Dalam urusan relasi muslim dan non-muslim, sudah banyak riwayatriwayat yang mencontohkan dan menjelaskan perilaku beliau, di mana tidak akan pernah dijumpai kekerasan dan paksaan, terlebih dalam urusan dakwah menyebarkan agama Islam. Padahal pada masanya, banyak sekali orang-orang non-muslim yang menentang dakwah beliau. Nabi dimusuhi, diperangi, disakiti bahkan ingin dibunuh oleh mereka. Namun, dengan sikap kebijaksanaan Nabi, beliau bisa menenangkannya. Nabi masih memiliki sisi humanis, yang tidak langsung menyikapi hal tersebut dengan emosi. Maka dari itu, Sekalipun ada

${ }^{20}$ Ibn Kas̄īr, Tafsir Ibn Kàīir, 121. 
beliau melakukan kekerasan dan peperangan, tentu saja itu semata-mata bukanlah beliau yang memulai dan menginginkan itu terjadi, melainkan hal itu beliau lakukan karena telah diserang terlebih dahulu dan sebagai upaya membela dan mempertahankan diri. ${ }^{21}$

Di samping itu, aksi nyata yang dilakukan Nabi SAW dalam menjalin relasi harmonis dengan pihak non-muslim dapat dilihat pada kebijksanaan beliau dalam melakukan perjanjian Hudaibiyah saat masih di Makkah, juga sama ketika beliau menetapkan piagam madinah setelah hijrah, pun kebijaksanaan-kebijaksaan lainnya yang beliau lakukan demi menjaga keharmonisan antar umat beragama pada masa itu. ${ }^{22}$

Namun di sisi lain, sebagaimana dijelaskan sebelumnya bahwa tidak dapat dipungkiri Nabi SAW juga pernah melakukan tindakan disharmonis terhadap pihak non-muslim dalam konteks tertentu, begitu juga halnya hadis-hadis Nabi yang cukup banyak terkesan bahwa beliau tidak harmonis, salah satunya seperti hadis tentang larangan mengucap salam kepada non-muslim. Sehingga banyak orang-orang muslim saat ini menjadi salah paham lantaran memahami hadis ini, di mana mereka hanya memahami secara tekstual saja, tanpa memperhatikan konteks lain terkait hadis tersebut. Lebih jelasnya akan dirincikan sebagai berikut mengenai beberapa riwayat-riwayat Nabi tentang interaksi muslim dengan nonmuslim.

a. Tetap menghormati jenazah orang yahudi

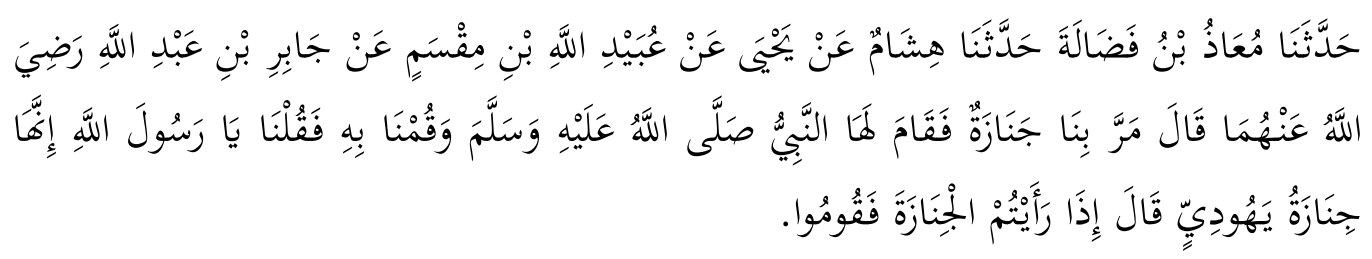

"Telah menceritakan kepada kami Mu'adz bin Fadhalah telah menceritakan kepada kami Hisyam dari Yahya dari 'Ubaidullah bin Muqsim dari Jabir bin 'Abdullah radliallahu 'anhua berkata,: 'Suatu hari jenazah pernah lewat di hadapan kami maka Nabi Shallallahu'alaihiwasallam berdiri menghormatinya dan kami pun ikut berdiri. Lalu kami tanyakan: 'Wahai Rasulullah, jenazah itu adalah

\footnotetext{
${ }^{21}$ Haidi Hajar Widagdo, "Etika Sosial Dalam Islam (Tinjauan atas Relasi Nabi dengan Pihak Non-Muslim)," Akademika 18, no. 2 (2013): 178.

${ }^{22}$ Haidi Hajar Widagdo, "Etika Sosial Dalam Islam (Tinjauan atas Relasi Nabi dengan Pihak Non-Muslim)," 180-183.
} 
seorang Yahudi.' Maka Beliau berkata,: 'Jika kalian melihat jenazah maka berdirilah'." (H.R. Bukhari).

b. Menjaga dan melindungi kafir mu'ahad

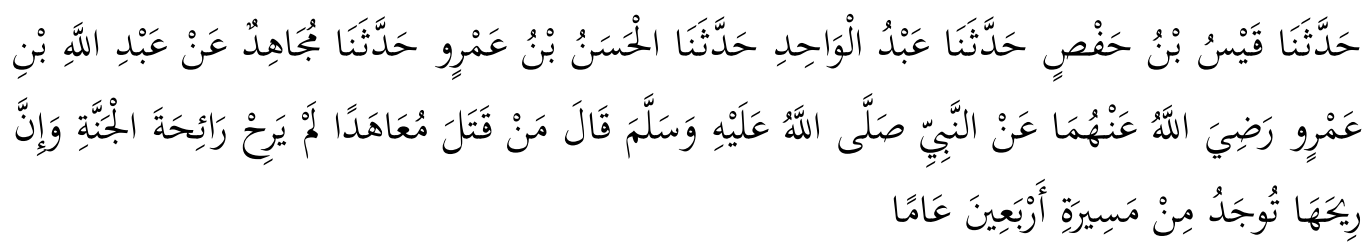

"Telah bercerita kepada kami Qais bin Hafsh telah bercerita kepada kami 'Abdul Wahid telah bercerita kepada kami Al Hasan bin 'Amru telah bercerita kepada kami Mujahid dari 'Abdullah bin 'Amru radliallahu 'anhu dari Nabi shallallahu 'alaihi wasallam bersabda: "Barang siapa yang membunuh mu'ahad (orang kafir yang terikat perjanjian) maka dia tidak akan mencium bau surga padahal sesungguhnya bau surga itu dapat dirasakan dari jarak empat puluh tahun perjalanan". (H.R. Bukhari)

c. Larangan menyakiti kafir $d z i m m \bar{\imath}$

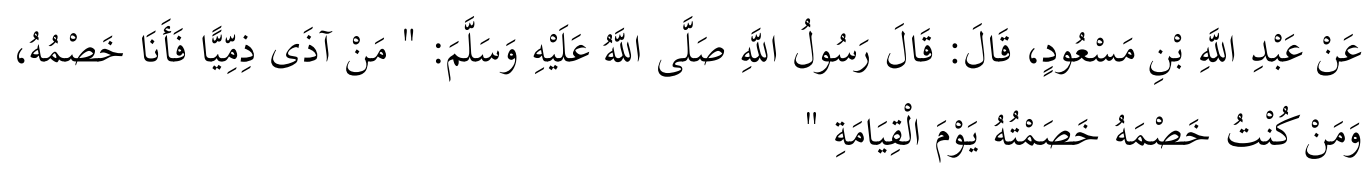

"Dari Abdullah bin Mas'ud, sesungguhnya Rasulullah SAW bersabda "siapa yang menyakiti seorang kafir dzimmi, maka aku kelak yang akan menjadi musuhnya. Dan siapa yang menjadikanku musuhnya, maka aku akan menuntutnya pada hari kiamat”. (H.R. Khatib Al-Baghdadi)." 23

Di samping itu, riwayat-riwayat Nabi mengenai hubungan beliau dengan non-muslim tidak hanya terbatas pada riwayat yang berbentuk qauliyah (perkataan) saja. Melainkan banyak juga riwayat-riwayat Nabi yang berupa fi'liyah (perbuatan) yang langsung beliau contohkan. Di mana riwayat tersebut bisa kita dapati di antaranya di dalam kitab-kitab Sirah Nabawiyah, Tarikh, Kitab Hadis, dan lain-lain. Di sana tampak jelas bagaimana sikap lapang dada dan murah hati yang dipraktekkan langsung oleh Nabi SAW terhadap orang-orang non-muslim. Adakalanya beliau mengunjungi mereka, menghormati mereka,

${ }^{23}$ Al-Khatib Al-Baghdadi, Tārīkh Baghdād, Juz 9 (Beirut: Darel Gharb El-Islamiy, 2002), 342 . 
berbuat baik, serta menjenguk mereka ketika sakit, dan saling memberi dan menerima sesuatu di antara mereka. ${ }^{24}$

Misalnya dalam kitab Sirah Nabawiyah, Ibnu Ishak menyebutkan bahwa ketika delegasi Nasrani dari Najran mengunjungi Rasulullah SAW di kota Madinah, mereka memasuki masjid beliau setelah waktu ashar. Mereka berdiri di dalamnya untuk melaksanakan ibadah mereka, sehingga beberapa orang dari kaum muslimin ketika itu ingin mencegah mereka. Namun Rasulullah bersabda: "biarkan mereka". Dengan menghadap arah Timur mereka tetap dapat meneruskan ibadahnya. Selain itu dalam kitab Al-Amwal, terdapat juga riwayat yang menyatakan bahwa Nabi SAW memberi sedekah kepada satu keluarga Yahudi, dan hal itu menjadi kebiasaan untuk mereka di masa-masa selanjutnya. ${ }^{25}$

Begitu juga Imam Bukhārī juga banyak menyebutkan riwayat-riwayat tentang ini. Seperti misalnya riwayat dari sahabat Anas bahwa Nabi pernah menjenguk seorang yahudi yang sedang sakit, sehingga membuat hati orang yahudi tersebut luluh dan akhirnya memeluk agama Islam. Riwayat lain juga menyebutkan bahwa ketika Nabi SAW wafat, baju besinya dalam keadaan tergadai pada seorang yahudi sebagai agunan harga makanan untuk keluarganya. Padahal sebenarnya tentu Nabi bisa saja meminjam dari para sahabatnya dan sudah tentu sahabatpun tidak akan menolak. Akan tetapi, beliau lakukan hal ini semata-mata untuk mengajari umatnya. Dan tidak sedikit juga riwayat yang mengatakan bahwa di saat tertentu, adakalanya Nabi menerima bantuan tenaga atau pikiran dari orang-orang non-muslim, baik di masa damai maupun saat perang. Dan ini semata-mata dilakukan Nabi karena beliau sudah sangat percaya kepada mereka dan tidak mengkhawatirkan tipu daya dan kejahatan dari mereka. ${ }^{26}$

Setidaknya beberapa riwayat ini telah dapat menunjukkan bahwa betapa Nabi Muhammad SAW sangat menginginkan keharmonisan antar sesama manusia, saling melindungi satu sama lainnya, atau penganut agama satu dengan penganut agama lainnya. Nabi memerintahkan dan mengajarkan kepada umatnya (umat Islam) untuk mewujudkan rahmatan lil älamīn (rahmat bagi seluruh alam). Sehingga jika diibaratkan, umat muslim itu seperti lebah, yang tidak akan mengganggu makhluk lainnya sebelum diganggu terlebih dahulu, dan akan memberikan manfaat kepada makhluk lain jika diperlakukan dengan baik.

\footnotetext{
${ }^{24}$ Yusuf Qardhawi, Minoritas Nonmuslim Di Dalam Masyarakat Islam, terj. Muhammad Baqir (Bandung: Karisma, 1994), 102.

${ }^{25}$ Yusuf Qardhawi, Minoritas Nonmuslim Di Dalam Masyarakat Islam, terj. Muhammad Baqir, 102-103.

${ }^{26}$ Yusuf Qardhawi, Minoritas Nonmuslim Di Dalam Masyarakat Islam, terj. Muhammad Baqir, 103-104.
} 
Demikianlah yang dicontohkan oleh Nabi dalam berhubungan dengan orangorang non-muslim.

\section{Kontekstualisasi Tafsir Nabawi \\ Dalam Mewujudkan Toleransi Di Era Milenial}

Sikap dan Perbuatan Nabi Muhammad SAW yang terekam dalam riwayatriwayat tersebut, semata-mata ialah bertujuan untuk menjadi contoh dan teladan bagi umatnya yang hidup jauh setelah beliau wafat. Nabi SAW telah berhasil menyihir orang-orang non-muslim menjadi takjub dengan Islam, sehingga tidak sedikit dari mereka yang terpengaruh dan akhirnya memeluk agama Islam. Namun, seiring berkembangnya zaman, di era milenial ini khususnya, nilai-nilai yang diajarkan Nabi mulai memudar dan menghilang. Banyak orang-orang muslim salah memahami teks al-Qur'an dan Sunnah mengenai relasi orang muslim dan non-muslim. Akibatnya, citra Islam tidak lagi seperti dulu. Islam saat ini seringkali dicap sebagai agama kekerasan dan tidak toleran. Sehingga keharmonisan antar umat beragama begitu sulit dirasakan.

Namun, tidak menutup kemungkinan, kegemilangan sebagaimana Islam awal itu dapat diraih kembali. Dengan merenungi, memahami dan mengaplikasikan kembali apa yang sudah dicontohkan oleh Nabi Muhammad melalui al-Qur'an dan Sunnah, nilai-nilai toleransi dalam mewujudkan keharmonisan tentu saja dapat terwujudkan. Nabi telah memberikan teladan bagaimana seharusnya sikap orang muslim dalam berinteraksi dengan nonmuslim, baik dalam konteks masyarakat dengan mayoritas muslim, maupun dalam masyarakat minoritas muslim. Hal ini sesuai dengan konteks dunia saat ini, meskipun Islam sudah menjadi agama yang mendominasi, tidak dapat dipungkiri juga bahwa terdapat daerah-daerah yang memang memiliki jumlah muslim yang minor ketimbang daerah lainnya, seperti negara-negara eropa. ${ }^{27}$

Ketika Islam telah menjadi sebuah agama yang mendominasi masyarakat, seperti pada kasus ketika umat Islam telah berjaya di masa-masa akhir kerasulan Muhammad, sudah menjadi sebuah kepastian bahwa pihak minoritas (nonmuslim) mendapat jaminan keamanan dari pihak muslim. Keberadaan, ketenteraman, dan kedamaian hidup pihak non-muslim wajib dila oleh pihak muslim. Inilah yang disebut dengan golongan kafir zimmy, yang secara tidak langsung mereka telah melakukan perjanjian hidup damai dengan pihak mayoritas (muslim). Dan ini mesti dipraktekkan di sebagian besar negara Indonesia yang mayoritas muslim. Orang-orang non-muslim di Indonesia berhak untuk dilindungi dan diperlakukan secara baik. ${ }^{28} \mathrm{Hal}$ ini sesuai dengan hadis-hadis Nabi

${ }^{27}$ Dina Mardiana, "Pemaknaan Toleransi dan Kebebasan Beragama Perspektif Tafsir Bil Ma’tsur," Jurnal Islamuna 5, no. 1 (2018): 25.

${ }^{28}$ Haidi Hajar Widagdo, "Etika Sosial Dalam Islam (Tinjauan atas Relasi Nabi dengan Pihak Non-Muslim),, 186. 
yang telah disebutkan sebelumnya, juga tidak bertentangan dengan QS. AlMumtahanah ayat 8-9 sebagaimana telah dijelaskan sebelumnya.

Adapun ketika agama Islam menjadi sebuah agama minoritas di sebuah daerah, seperti misalnya sebagian besar negara-negara eropa, di mana orangorang muslim seringkali didiskriminasi dan diperlakukan secara semena-mena. Dalam kondisi seperti ini, jika pihak non-muslim telah berlaku dzalim dan berbuat aniaya terlewat batas terhadap orang muslim, maka orang muslim minoritas tersebut dapat membalas serangan mereka. Melakukan kekerasan dalam hal ini dibenarkan, karena semata-mata dilakukan sebagai bentuk pembelaan diri atas tindak diskriminasi yang dilakukan oleh pihak mayoritas (non-muslim) tersebut. ${ }^{29}$ Memang seperti inilah yang dipraktekkan oleh Nabi SAW. Dalam sejarahnya, semua peperangan yang dilakukan oleh Nabi ialah murni merupakan upaya untuk menjaga dan mempertahankan jiwa mereka. Dan tentu saja hal ini sesuai dengan ayat-ayat qitāl di dalam al-Qur'an seperti QS. Al-Baqarah ayat 190 dan lain-lain. Sehingga berdasarkan penjelasan ini, tuduhan-tuduhan yang menyatakan Islam sebagai agama kekerasan tidak dapat dibenarkan.

\section{Kesimpulan}

Berdasarkan pemaparan di atas, tulisan ini memiliki titik point penting yang dapat dijadikan kesimpulan. Nabi Muhammad SAW selaku mufassir al-Qur'an pertama, beliau telah berhasil menjelaskan beberapa ayat al-Qur'an kepada para sahabatnya. Keberhasilan tersebut dapat dilihat dari bahwasannya beliau tidak hanya sekedar memberi pemahaman dan penjelasan kepada para sahabat terkait suatu ayat tertentu, melainkan beliau juga ikut memberi contoh dan teladan dalam mengaplikasikan ayat-ayat tersebut, dan tentu saja ini juga merupakan bagian dari penjelasan al-Qur'an itu sendiri. Oleh karenanya, tidak heran jika Aisyah menyebut akhlak beliau ialah akhlak al-Qur'an.

Mengenai hubungan antara muslim dengan non-muslim, secara umum Nabi Muhammad SAW memberikan dua bentuk relasi, yaitu relasi harmonis dan relasi disharmonis. Namun, sangat perlu disadari, berdasarkan riwayat-riwayat Nabi SAW terkait relasi tersebut, disimpulkan bahwa pada dasarnya beliau selalu berusaha dan sangat ingin menjalin relasi yang harmonis dengan non-muslim. Meskipun dalam prakteknya, beliau juga pernah melakukan kekerasan dan peperangan terhadap non-muslim yang semata-mata beliau lakukan dalam rangka menjaga dan menyelamatkan jiwa, agama, dan umat-umatnya. Ketika situasi aman dan tentram, dalam artian tidak ada ancaman dan gangguan yang datang dari luar, Nabi selalu memberikan teladan yang baik, dengan bersikap ramah,

${ }^{29}$ Haidi Hajar Widagdo, "Etika Sosial Dalam Islam (Tinjauan atas Relasi Nabi dengan Pihak Non-Muslim)," 187. 
santun, dan tetap menyayangi serta menghargai orang-orang yang berbeda keyakinan dengan beliau.

\section{Daftar Pustaka}

Abdul Rahim, Muhammad. Al-Tafs̄̄r Al-Nabawī Khașāiṣuhu wa Maṣādiruḥu. Kairo: Maktabah Az-Zahra, 1992.

Ansori, Isa. "Tafsir Al-Qur'an Dengan Al-Sunnah.” Kalam 11, no. 2. (2017).

Assagaf, Ja'far. "Hubungan Muslim Dengan Non-Muslim Perspektif Hadis." Pascasarjana UIN Syarif Hidayatullah Jakarta.

Azmi, Ahmad Sanusi dan Mohd Yusuf Ismail. "Konsep Rahmatan Lil Alamin Dalam Hadith: Penerokaan Makna Serta Aplikasi Di Malaysia." Journal of Hadith Studies 3, no. 1 (2018)

Al-Baghdadī, Al-Khatib. Tarīkh Baghdad. Beirut: Darel Gharb El-Islamiy, 2002.

Difinubun, Rafli. "Perjanjian Hudaibiyah (suatu Analisis Historis tentang Penyebaran Agama Islam di Jazirah Arab)." Rihlah: Jurnal Sejarah dan Kebudayaan 6, no.1 (2018).

Dirun. "Hubungan Muslim Non-Muslim dalam Interaksi Sosial (Study Analisis Penafsiran Thabathabai dalam Kitab Tafsir al-Mizan)." Universitas Islam Negeri Walisongo Semarang, 2015.

Hajar Widagdo, Haidi. "Etika Sosial Dalam Islam (Tinjauan atas Relasi Nabi dengan Pihak Non-Muslim)." Akademika 18, no. 2 (2013).

Hariyanto. "Relasi Kredibilitas Da'i Dan Kebutuhan Mad'u Dalam Mencapai Tujuan Dakwah." Tasamuh 15, no. 2 (2018).

Hijriyanti, Tri. "Peranan Pembimbing dalam Meningkatkan Hapalan Al-Qur'an Santri." Irsyad: Jurnal Bimbingan, Penyuluhan, Konseling, dan Psikoterapi Islam 6, no. 3 (2018).

Kasiir, Ibnu. Tafsir Ibn Kàīir. t.k: Darut Taibah, 2001.

Mardiana, Dina. "Pemaknaan Toleransi dan Kebebasan Beragama Perspektif Tafsir Bil Ma’tsur." Jurnal Islamuna 5, no. 1 ( 2018).

Mustofa, Muhammad Arif. "Kerukunan Umat Beragama (StudiAnalisis Tentang Non Muslim, Ahlul Kitab \& Pluralisme).” Mizani 9, no. 1 (2015). 
Qardhawi, Yusuf. Minoritas Nonmuslim Di Dalam Masyarakat Islam, terj. Muhammad Baqir. Bandung: Karisma, 1994.

Rejeki, Roro Sri dan Lia Ulfah Farida. "Pola Interaksi Sosial Keagamaan Antara Penganut Agama Islam dan Kristen.” Jurnal Religious 2, no. 2 (2018).

Rohman, Fathur, dan Ahmad Ali Munir. "Membangun Kerukunan Umat Beragama Dengan Nilai-Nilai Pluralisme Gus Dur." Jurnal An-Nuha 5, no. 2 (2018).

Shihab, Alwi. Islam Inklusif Menuju Sikap Terbuka Dalam Beragama. Bandung: Mizan, 1997.

Umar, Ratnah. "Jāmi 'Al-Bayān 'An Ta'wīl Āyi Al-Qur’ān (Manhaj/Metode Penafsirannya)." Al Asas 1, no. 2 (2018). 